\title{
ANALISIS UNDANG-UNDANG NOMOR 2 TAHUN 2012 TENTANG PEMBERIAN GANTI RUGI ATAS PROYEK PENGADAAN TANAH UNTUK KEPENTINGAN UMUM PERSPEKTIF HUKUM ISLAM
}

\author{
Chamim Tohari \\ Universitas Muhammadiyah Surabaya \\ amimzone@yahoo.co.id
}

\begin{abstract}
This research focused to analyze arrangements about implementation of the loss subtitution gift for a land deliverance in the process of the land supplying which is attached in Indonesian's Contitution Number 2 Year 2012 in the perspective of Islamic Law. The problem which will answered in the research is about the arrangements is it according to the concept of the loss subtitution gift in Islamic law? The research is a normative law research library research type which is use a comparative analysis method as a method used to supply the answer of the problem in the research. The results of the research there are: First, in the perspective of fiqh muamalah, the arrangements about loss substitution gift in the land supplying for the general importance reconstruction has been according to the concept of kafâlah in the conference and the loss substitution gift stage when agreement about the amount of the loss substitution reached . However in the next stage when the owner of land do not agree about amount of the loss substitution gift, the constitution has not been according to the concept ot kafâlah particularly, and the principles of the fiqh muamalah generally. Second, based on the fiqh siyasah perspective, the constitution can be concluded that it has been according to the principles of fiqh siyasah. Because the infra structure development for the general importance has been relevance to the maslahah of the citizen and the nation. Based on this argument, all of the citizen of Indonesia have to obey the constitution for the maslahah realization.
\end{abstract}

Keywords: loss subtitution, the land supplying, Muamalah, Kafâlah, Siyasah. 


\begin{abstract}
Abstrak
Penelitian ini difokuskan untuk menganalisis aturan-aturan tentang pelaksanaan pemberian ganti rugi atas pembebasan lahan dalam proses pengadaan tanah yang tercantum dalam Undang-Undang Nomor 2 Tahun 2012 dalam perspektif hukum Islam. Permasalahan yang akan dijawab dalam penelitian ini adalah apakah aturan pemberian ganti rugi pengadaan tanah dalam Undang-Undang Nomor 2 Tahun 2012 sejalan dengan konsep ganti rugi dalam hukum Islam? Penelitian ini adalah penelitian hukum normatif dengan model penelitian pustaka (library research) yang menggunakan metode analisis komparatif (comparative analysis) sebagai metode yang ditempuh untuk menjawab permasalahan dalam penelitian ini. Hasil penelitian ini adalah: Pertama, dalam perspektif fiqh muamalah, aturan tentang ganti rugi pengadaan tanah untuk kepentingan umum telah sejalan dengan konsep kafâlah pada tahapan musyawarah dan pemberian ganti rugi setelah disepakati besaran ganti ruginya. Namun dalam tahap berikutnya dimana pemilik tanah atau tertanggung tidak menyepakati besaran ganti ruginya, aturan pemberian ganti rugi dalam Undang-Undang Nomor 2 Tahun 2012 tidak sejalan dengan konsep kafâlah secara khusus, dan prinsip-prinsip fiqh muamalah secara umum. Kedua, dalam perspektif fiqh siyasah, aturan tentang ganti rugi pengadaan tanah untuk kepentingan umum dapat dikatakan sejalan dengan qaidah dan konsep fiqh siyasah. Karena pembangunan untuk kepentingan umum memiliki relevansi dengan kemaslahatan bangsa dan Negara, maka suatu aturan hukum yang mengaturnya pun harus ditaati oleh seluruh rakyat Indonesia demi terwujudnya kemaslahatan tersebut.
\end{abstract}

Kata Kunci: Ganti rugi, Pengadaan tanah, Muamalah, Kafâlah, Siyasah.

\title{
PENDAHULUAN
}

Tanah merupakan aset penting bagi manusia yang mempunyai peranan strategis dalam kehidupan karena mempunya fungsi strategis baik sebagai aset sosial maupun sebagai aset negara. Sebagai aset sosial misalnya tanah berfungsi sebagai sarana pengikat kesatuan sosial masyarakat di Indonesia dalam kehidupan bernegara. Adapun tanah sebagai aset negara tanah berfungsi sebagai salah satu modal pokok dalam pembangunan. ${ }^{1}$

${ }^{1}$ Achmad Rubaie. 2007, Hukum Pengadaan Tanah Untuk Kepentingan Umum, (Malang: Bayu media Publishing,), hal. 12. 
Sebagai bentuk real dari manifestasi Pasal 33 ayat (3) Undang-Undang Dasar Negara Republik Indonesia Tahun 1945 yang menegaskan bahwa bumi, air dan kekayaan alam yang terkandung di dalamnya yang berada di wilayah Negara Kesatuan Republik Indonesia berada dibawah kekuasaan negara maka lahirlah Undang-Undang Nomor 5 Tahun 1960 tentang Peraturan Dasar Pokok-Pokok Agraria yang kemudian disebut Undang-Undang Pokok Agraria. Di dalam Undang-Undang ini yakni pada Pasal 2 ayat (1) ditegaskan bahwa bumi, air dan ruang angkasa adalah kekayaan alam dimana penguasaan tetingginya ada pada negara sebagai organisasi kekuasaan milik seluruh rakyat.

Apabila dipahami sebenarnya hak menguasai negara adalah suatu konsep yang bertolak pada pemahaman bahwa negara sebagai suatu organisasi kekuasaan dari seluruh rakyat yang memiliki kekuatan untuk mempengaruhi pihak lain sehingga tampak bahwa kekuasaan sentral dipegang oleh negara. Karenanya tanah yang memiliki fungsi sebagai faktor produksi yang utama seharusnyalah berada dalam kekuasaan negara. Meskipun demikian tanah yang dikuasai oleh negara tidak lantas menjadi milik negara, tetapi negara memiliki kekuasaan membuat kebijakan tentang pengelolaan tanah.

Berkaitan dengan itu, pembangunan proyek pemerintah sudah barang tentu memerlukan tanah. Sementara tanah yang ada selama ini dapat berupa tanah yang dikuasai secara langsung atas nama negara (tanah negara) atau tanah yang sudah dimiliki atas nama suatu subyek hukum (tanah hak). Jika kondisi tanah yang diperlukan untuk pembangunan itu adalah tanah negara, maka pengadaan tanahnya tidak akan sulit, karena pemerintah dapat langsung mengajukan permohonan hak atas tanah tersebut untuk kemudian dapat langsung dilakukan pembangunan. Tetapi untuk saat ini tanah dengan status milik negara sangat terbatas, yang ada adalah tanah hak yang dapat berupa Hak Milik, Hak Guna Usaha, Hak Guna bangunan, dan Hak pakai.

Proyek pembangunan yang diadakan untuk membangun infrastruktur guna mempermudah kegiatan yang beorientasi pada kepentingan umum dewasa ini menuntut adanya ketersediaan tanah secara cepat. Namun untuk merealisasikan pengadaan tanah diperlukan suatu payung hukum. Kebijakan yang dikeluarkan oleh pemerintah dalam bentuk Peraturan Presiden 65 Tahun 2006 yang merupakan penyempurnaan dari Peraturan Presiden 36 Tahun 2005 yang mengatur Pengadaan Tanah bagi Pelaksanaan Pembangunan demi Kepentingan Umum tersebut dapat menjadi salah satu payung hukum bagi pemerintah guna memudahkan proses penyediaan tanah untuk pembangunan. Melalui Peraturan Presiden di atas, pemerintah mempunyai 
kewenangan untuk menguasai tanah milik masyarakat yang dibutuhkan untuk pembangunan proyek-proyek pemerintah untuk kepentingan umum.

Namun demikian meskipun pemerintah memiliki kekuasaan mengatur penggunaan kekayaan alan dalam negeri, dalam menempuh prosedur dan proses pengadaan tanah tidak boleh sewenang-wenang. Pengadaan tanah untuk pembangunan hanya dapat dilakukan berdasarkan peraturan hukum yang berlaku seperti melalui cara pemberian ganti rugi yang diberikan kepada pemegang hak atas tanah tersebut. ${ }^{2}$

Isu pemberian ganti rugi atas proyek pengadaan tanah untuk kepentingan umum bisa jadi tidak begitu sensitif jika tanah yang dicabut hak kepemilikannya adalah milik orang kaya dimana tanah tersebut tidak menjadi sumber primer penghidupan bagi keluarganya. Masalah yang lazim muncul dalam pengadaan tanah adalah jika pengadaan tanah itu dilakukan melalui penggusuran paksa terhadap tanah yang menjadi sumber pencaharian atau bahkan pemukiman yang dibangun oleh penduduk sendiri, sementara pemerintah tidak menyiapkan ganti kerugian yang memadai atau program pemukiman kembali (resettlement/rehousing) bagi masyarakat yang dicabut haknya atas tanah. Disinilah prinsip keadilan hukum yang termaktub dalam Undang-Undang Pengadaan Tanah diuji.

Berawal dari asumsi penulis bahwa ketika suatu Undang-Undang yang telah dibuat dan dijalankan sebagaimana mestinya, maka tentunya warga negara akan mematuhinya sehingga tidak akan terjadi permasalahan-permasalahan pembebasan lahan untuk kepentingan umum sebagaimana dijelaskan di atas. Karena dalam penegakan hukum berdasarkan Undang-Undang tentunya terkandung unsur penegakan keadilan yang menjadi substansi hukum tersebut. UndangUndang Nomor 2 Tahun 2012 secara jelas telah memberikan aturan tentang prosedur yang harus ditaati baik oleh pemerintah sebagai pemilik proyek pembangunan.

Oleh karena itu melalui penelitian ini penulis hendak menganalisis aturan-aturan tentang pelaksanaan pemberian ganti rugi atas pembebasan lahan dalam proses pengadaan tanah yang tertera dalam Undang-Undang Nomor 2 Tahun 2012 dalam perspektif hukum Islam. Adapun permasalahan yang akan dijawab dalam penelitian ini adalah apakah aturan pemberian ganti rugi pengadaan tanah dalam Undang-Undang Nomor 2 Tahun 2012 sejalan dengan konsep ganti rugi dalam hukum Islam? Penelitian ini adalah penelitian hukum normatif dengan model penelitian

\footnotetext{
${ }^{2}$ Bernhard Limbong. 2011, Pengadaan Tanah Untuk Pembangunan :Regulasi, Kompensasi Penegakan Hukum, (Jakarta: Pustaka Margareta), hal 131.
} 
pustaka (library research) yang menggunakan metode analisis komparatif (comparative analysis) sebagai metode yang ditempuh untuk menjawab permasalahan dalam penelitian ini.

\section{PEMBAHASAN}

\section{Definisi}

Berdasarkan Undang-Undang Nomor 2 Tahun 2012, "Pengadaan Tanah" dimaknai sebagai kegiatan menyediakan tanah dengan cara memberi ganti kerugian yang layak dan adil kepada pihak yang berhak. ${ }^{3}$ Pengadaan tanah merupakan perbuatan hukum yang dalam hal ini dilakukan oleh pemerintah guna mendapatkan tanah untuk kepentingan tertentu seperti pembangunan infrastruktur dengan cara memberikan ganti kerugian kepada pemilik tanah (baik individu maupun instansi) berdasarkan prosedur dan besaran nominal yang telah ditentukan oleh undang-undang. Dapat dikatakan bahwa pemerintah dalam rangka pembangunan berbagai fasilitas umum selalu memerlukan tanah. Namun demikian pemerintah memiliki keterbatasan dalam hal ketersediaan tanah untuk pembangunan yang dikuasai oleh Negara (sebagaimana dijelaskan dalam Pasal 2, 6 dan 18 Undang-Undang Pokok Agraria) sehingga untuk keperluan pembangunan tersebut tidak mencukupi. Karena itu untuk mencukupi kebutuhan akan tanah untuk mewujudkan pembangunan yang memadai berdasar Pasal 6 Undang-Undang Pokok Agraria tentang fungsi sosial hak atas tanah, pemerintah menempuh cara dengan jalan mengambil tanah-tanah hak (baik hak individu maupun hak instansi berbadan hukum) dengan memberikan ganti rugi yang disepakati. ${ }^{4}$

Adapun pengertian "Kepentingan Umum" dalam Pasal 1 angka 6 Undang-Undang Nomor 2 Tahun 2012 dimaknai sebagai kepentingan bangsa, negara, dan masyarakat yang harus diwujudkan oleh pemerintah dan digunakan sebesar-besarnya untuk kemakmuran rakyat. Jika dibandingkan dengan pengertian kepentingan umum dalam Peraturan Presiden Nomor 36 Tahun 2005, kepentingan umum hanya didefiniskan sebagai kepentingan sebagian besar lapisan masyarakat. Sedangkan dalam Peraturan Presiden Nomor 65 Tahun 2006, kepentingan umum tidak didefinisikan secara jelas dan hanya diatur perubahan jenis-jenisnya saja sebagaimana tertera dalam Pasal 5. Perumusan ulang tentang batasan kepentingan umum dalam UndangUndang tersebut sangat penting sebagai batu uji jika terdapat perbedaan pandangan mengenai

\footnotetext{
${ }^{3}$ Pasal 1 UU Nomor 2 Tahun 2012 dan Pasal 1 Perpres 71 Tahun 2012.

${ }^{4}$ Pasal 27 huruf a, 34, 40 UUPA yunctis PP 40 Tahun 1996, Peraturan Presiden Nomor 65 Tahun 2006.
} 
definisi kepentingan umum. ${ }^{5}$ Begitu pula jika didapati jenis baru dari cakupan kepentingan umum yang belum dijelaskan pada Pasal 10 Undang-Undang Nomor 2 Tahun 2012 tersebut.

Harus dipahami bahwa tidak semua kegiatan pengadaan tanah dapat digolongkan sebagai pengadaan tanah untuk kepentingan umum. Karena itu pasal 10 Undang-Undang Nomor 2 Tahun 2012 menentukan kegiatan pengadaan tanah yang termasuk dalam ranah kepentingan umum sebagai berikut:

a. Pertahanan dan keamanan nasional;

b. Jalan umum, jalan tol, terowongan, jalur kereta api, stasiun kereta api, dan fasilitas operasi kereta api;

c. Waduk, bendungan, bendung, irigasi, saluran air minum, saluran pembuangan air dan sanitasi,

d. Bangunan pengairan lainnya;

e. Pelabuhan, bandar udara, dan terminal;

f. Infrastruktur minyak, gas, dan panas bumi;

g. Pembangkit, transmisi, gardu, jaringan, dan distribusi tenaga listrik;

h. Jaringan telekomunikasi dan informatika Pemerintah;

i. Tempat pembuangan dan pengolahan sampah;

j. Rumah sakit Pemerintah/Pemerintah Daerah;

k. Fasilitas keselamatan umum;

1. Tempat pemakaman umum Pemerintah/Pemerintah Daerah;

m. Fasilitas sosial, fasilitas umum, dan ruang terbuka hijau publik;

n. Cagar alam dan cagar budaya;

o. Kantor Pemerintah/Pemerintah Daerah/desa;

p. Penataan permukiman kumuh perkotaan dan/atau konsolidasi tanah, serta perumahan untuk masyarakat berpenghasilan rendah dengan status sewa;

q. Prasarana pendidikan atau sekolah Pemerintah/Pemerintah Daerah;

r. Prasarana olahraga Pemerintah/Pemerintah Daerah; dan

s. Pasar umum dan lapangan parkir umum." 6

Sebagai konsekwensi dari pasal di atas, pengadaan tanah untuk kepentingan umum hanya dianggap sah apabila memenuhi syarat-syarat berikut:

${ }^{5}$ Terkait dengan permasalahan tersebut telah ada putusan Mahkamah Konstitusi atas Perkara Nomor 50/PUU-X/2012 mengenai judicial review Undang-Undang Nomor 2 Tahun 2012.

${ }^{6}$ Pasal 10 UU Nomor 2 Tahun 2012. 
1. Klasifikasi kegiatan pengadaan tanah untuk kepentingan umum terbatas pada tujuh (butir) kegiatan yang telah ditentukan Pasal 5 Peraturan Presiden Nomor 65 Tahun 2006;

2. Pembangunan untuk kepentingan umum hanya terbatas pada 19 (butir) kegiatan pembangunan sebagaimana yang disebutkan Pasal 10 di atas, bentuk pembangunan diluar itu tidak dianggap sebagai pembangunan untuk kepentingan umum.

3. Kegiatan pembangunan dilakukan oleh Pemerintah Pusat atau Pemerintah Daerah; Berdasarkan pasal 10 di atas, pelaksana dan proses pelaksanaan kegiatan pembangunan untuk kepentingan umum hanya dapat dilaksanakan dan dibiayai oleh pemerintah pusat atau pemerintah daerah. $^{7}$

4. Hasil dari pembangunan tersebut menjadi milik Pemerintah Pusat atau Pemerintah Daerah. Syarat ini membatasi bahwa kegiatan pembangunan untuk kepentingan umum yang memerlukan pengadaan tanah karena adanya kebutuhan tanah bagi pelaksanaan pembangunan hanya dapat dimiliki oleh Pemerintah Pusat atau Pemerintah Daerah.

Menurut hemat penulis, konsepsi pengadaan tanah untuk kepentingan umum dapat dimaknai sebagai pengadaan tanah yang dimaksudkan untuk memenuhi kebutuhan pembangunan yang dimana hasilnya adalah untuk kepentingan bangsa dan negara, terutama rakyat secara umum dan tidak dimaksudkan untuk mencari keuntungan dengan memperhatikan dampaknya dari aspek-aspek sosial, politik, ekonomi, psikologis serta aspek lainnya dengan mengacu pada dasar asas-asas pembangunan nasional. Berdasarkan pengertian tersebut maka kegiatan pengadaan tanah untuk kepentingan umum haruslah dapat dirasakan manfaatnya oleh setidaknya - sebagian besar rakyat Indonesia, bukan hanya dinikmati oleh pihak-pihak tertentu seperti pemerintah dan investor.

\section{Konsep Ganti Rugi Dalam Undang-Undang Nomor 2 Tahun 2012}

Definisi ganti rugi yang dimaksudkan dalam Undang-Undang Nomor 2 Tahun 2012 telah ditegaskan pada bab 1 pasal 1 poin 10, bahwa yang dimaksud dengan ganti rugi dalam konteks

\footnotetext{
${ }^{7}$ Kewenangan Pemerintah daerah dalam melaksanakan pembangunan untuk kepentingan umum tersebut sejalan dengan salah satu kewajibannya dalam menyelenggarakan otonomi yaitu menyediakan fasilitas sosial dan fasilitas umum yang layak. Hal ini termuat dalam Pasal 22 huruf g Undang-Undang Nomor 32 Tahun 2004. Pada Pasal sebelumnya, yakni Pasal 13 ayat (1) huruf a dan d, serta Pasal 14 ayat (1) huruf a dan d dijelaskan bahwa urusan wajib yang menjadi kewenangan pemerintah daerah provinsi dan pemerintah daerah kabupaten/kota di antaranya meliputi perencanaan dan pengendalian pembangunan serta penyediaan sarana dan prasarana umum.
} 
ini adalah "Penggantian yang layak dan adil kepada pihak yang berhak dalam proses pengadaan tanah."

Selanjutnya tentag prosedur pemberian ganti rugi dijelaskan pada pasal 37 hingga pasal 44. Pada pasal 37 dijelaskan bahwa untuk menetapkan besaran ganti rugi atas tanah yang terkena proyek pembangunan untuk kepentingan umum dilakukan melalui musyawarah dengan pihakpihak yang berhak menerima ganti rugi tersebut dalam waktu 30 hari setelah petugas penilai harga tanah menetapkan besaran harga tanah sesuai harga yang berlaku pada umumnya (pasal 37). Apabila dalam musyawarah tersebut tidak dicapai kesepakatan antara pemilik tanah dengan panitian pengadaan tanah, maka pemilik tanah dihimbau untuk mengajukan keberatan ke Pengadilan Negeri setempat dalam waktu 14 hari kerja (pasal 38). Apabila di antara pemilik tanah menolak besaran ganti rugi yang telah ditetapkan panitia pengadaan tanah, tetapi tidak mengajukan keberatan ke Pengadilan Negeri dalam waktu yang ditetapkan Undang-Undang, maka pemilik tanah dianggap menerima besaran ganti rugi tersebut (pasal 39).

Setelah dalam waktu 30 hari Pengadilan Negeri memutuskan besaran harga ganti rugi yang diajukan, putusan tersebut kemudian diberikan kepada pemilik tanah yang telah mengajukan keberatan tersebut. Apabila pemiliki tanak masih keberatan dengan hasil putusan Pengadilan negeri, maka dihimbau untuk mengajukan kasasi ke Mahkamah Agung dalam waktu paling lama 14 hari kerja setelah putusan tersebut diterimanya (pasal 38 ayat 3). Adapun Mahkamah Agung diwajibkan memberikan putusan paling lama 30 hari kerja dimulai sejak permohonan kasasi diterima (pasal 38 ayat 4). Putusan Mahkamah Agung tersebut kemudian menjadi dasar besaran pemberian ganti rugi oleh pemerintah kepada masyarakat pemilik tanah (pasal 38 ayat 5).

Prosedur pemberian ganti rugi diberikan secara langsung oleh panitia pengadaan tanah kepada pemilik tanah yang berhak menerimanya (pasal 40). Dalam hal pemilik tanah menolak besaran ganti rugi baik yang telah ditetapkan oleh panitia pengadaan tanah, Pengadilan Negeri maupun Mahkamah Agung, maka uang ganti rugi tersebut dititipkan kepada Pengadilan Negeri setempat (pasal 42 ayat 1). Selain itu penitipan ganti rugi juga dilakukan dalam kondisi pemilik tanah tidak diketahui keberadaannya, objek tanah yang akan diberikan ganti rugi sedang menjadi objek perkara di pengadilan; masih dipersengketakan kepemilikannya; diletakkan sita oleh pejabat yang berwenang; atau masih menjadi jaminan di bank. Hal ini dijelaskan pada pasal 42 ayat 1 dan 2 Undang-Undang Nomor 2 Tahun 2012. 
Demikian konsep dan pengaturan mengenai pemberian ganti rugi atas tanah yang terkena proyek pengadaan tanah untuk pembangunan kepentingan umum.

\section{Analisis Ganti Rugi Dalam Perspektif Hukum Islam}

Untuk melihat sejauh mana relevansi pasal-pasal yang mengatur pemberian ganti rugi tanah dari sudut pandang hukum Islam, maka penulis dalam hal ini menggunakan dua perspektif, yakni perspektif fiqh muamalah dan perspektif fiqh siyasah.

\section{Perspektif Fiqh Muamalah}

\section{Kafâlah}

Masalah ganti atas kerugian dalam fiqh mualamah umumnya dibahas pada bab tentang kafâlah. Adapun kafâlah sendiri berasal dari kata كفل, yang mana sinonim dengan kata ضمن, yang secara terminologis bermakna menanggung atau mengumpulkan. Adapun secara istilah, kata kafâlah artinya mengumpulkan suatu tanggungan kepada tanggungan yang lain dalam penuntutan terhadap jiwa, harta, atau benda. ${ }^{8}$ Sedangkan dhaman secara bahasa berarti garansi atau jaminan. Secara istilah misalnya dalam kitab Majallah al-Ahkâm al-Adliyah, kata dhaman didefinisikan sebagai "Memberikan sesuatu yang serupa dalam bentuk harga atas sesuatu yang serupa tersebut.",9

Kata dhaman seringkali digunakan oleh pada ulama fiqh berkaitan dengan masalah pertanggungan terhadap harta. Dalam beberapa kitab fiqh mazhab Maliki, Syafi'i, Hanbali dan Zhahiri pada bab kafâlah terdapat sub bab yang bisanya diberi judul kitab al-dhaman atau bab al-dhaman. Selain itu ada juga fuqaha yang memasukkan masalah dhaman ke dalam pembahasan pada bab zharar. Yang disebutkan terakhir lebih banyak digunakan dalam kitabkitab fiqh mazhab Hanafi. ${ }^{10}$

Konsep dhaman dalam mazhab Hanafi sering dikaitkan dengan masalah zharar, yakni seseorang yang melakukan tindakan yang mengakibatkan rusaknya atau hilangnya kepemilikan orang lain atas sesuatu yang berharga baik itu harta ataupun aset-aset lainnya. Bagi orang tersebut dikenakan hukuman wajibnya mengganti kerugian yang dialami oleh orang yang

${ }^{8}$ Abdurrahman al-Jaziri, Fiqh 'alâ Madzâhib al-Arba'ah, juz 3, (Beirut: Dâr al-Fikr, th), hal. 221.

${ }^{9}$ Majallah al-Ahkâm al-Adliyah. 2012, pasal 416, (Istanbul: Marmara Universitesi Yayinlari).

${ }^{10}$ Kemal Yildiz. 2013, Islam Sorumluluk Hukuku, (Istanbul: Marmara Universitesi Ilahiyat Fakultesi Yayinlari), hal. 34-35. 
kehilangan. ${ }^{11}$ Adapun masalah ganti rugi atas proyek pengadaan tanah bagi kepentingan umum yang dilakukan oleh pemerintah Republik Indonesia, setidaknya dapat dilihat dengan konsep dhaman atau kafâlah ini. Karena adanya kesamaan dalam hal objek kajiannya, yakni adanya kerugian yang ditimbulkan atas suatu perbuatan.

Dalam konsep kafâlah, ada beberapa rukun yang harus dipenuhi untuk menjamin keshahihan akad tersebut dimana masalah ganti rugi pengadaan tanah dapat diperbandingkan dengannya, yaitu:

(1) Sîghat. Sîghat yang dimaksud adalah adanya ijab qabul dalam yang menunjukkan adanya kesepakatan antara penanggung dn pihak yang ditanggung. Ulama-ulama mazhab tidak menentukan atau memberikan syarat-syarat tertentu untuk keabsahan sîghat, artinya shigat atau ucapan ijab qabul dapat dilakukan dengan kalimat apapun, yang jelas dapat menunjukkan suatu kesepakatan. Dalam pengaturan pemberian ganti rugi pengadaan tanah sebagaimana yang diatur dalam Undang-Undang Nomor 2 Tahun 2012, tidak dijelaskan adanya ijab qabul secara eksplisit, tetapi adanya tahapan musyawarah penentuan harga tanah yang akan diberikan ganti rugi atasnya merupakan bentuk lain dari ijab qabul. Jadi dapat dapat dikatana bahwa unsur kafâlah yang pertama ini telah terpebuhi dalam Undang-Undang tersebut.

(2) Dhâmin atau kâfil. Yaitu pihak yang menanggung atau menjamin atau yang membayar kerugian. Dalam konteks ganti rugi pengadaan tanah, pemerintah adalah dhâmin sebab berposisi sebagai pihak yang menjalankan proyek pengadaan tanah.

(3) Madhmûn atau makfûl lahu. Adalah para pemegang hak atas tanah yang berhak menerima uang ganti rugi dari penanggung. Madhmûn atau makfûl lahu memiliki hak untuk ditanggung karena kepemilikannya atas tanah menjadi hilang oleh perbuatan dhâmin.

(4) Makfûl bih. Adalah objek yang ditanggung atau objek yang dengan sebab hilangnya maka diberikan ganti rugi, yang mana dalam hal ini objek yang ditanggung adalah tanah.

Dari uraian di atas dapat dikatakan bahwa seluruh rukun untuk terjadinya kafâlah pada kasus pengadaan tanah untuk pembangunan kepentingan umum telah terpenuhi. Apabila dilihat dari objek kafâlah-nya maka hal ini termasuk kafâlah bi al-mâl, yaitu suatu bentuk kafâlah dimana penanggung ganti rugi terikat untuk membayar kewajiban yang bersifat harta. ${ }^{12}$

\footnotetext{
${ }^{11}$ Ibid, hal 130.

${ }^{12}$ Sayid Sabiq. 1981, Fiqh al-Sunnah, juz 3, (Beirut: Dar al-Fikr), hal. 286.
} 
Dalam lingkup kafâlah bi al-mâl, ganti rugi dalam pengadaan tanah untuk pembangunan dapat dikategorikan dalam kelompok kafâlah bi al-dain, yaitu kewajiban penanggung atau penjamin ( $k \hat{a} f i l)$ untuk melunasi hutang yang berada pada tanggung jawabnya. Karena ganti rugi dalam konteks ini dapat dimaknai sebagai bentuk hutang pemerintah kepada pemilik tanah atas hilangnya hak kepemilikan tanah dari pemiliknya akibat adanya proyek pembangunan yang dilakukan.

Kafâlah dalam hal ini juga dapat dimaknai sebagai bentuk kafâlah bi al-'ain atau kafâlah bi al-taslîm, yakni kewajiban menyerahkan barang yang dijual kepada pembeli. ${ }^{13}$ Dalam hal ini pembebasan hak atas tanah dari pemiliknya dapat dimaknai sebagai suatu akad jual beli, sehingga yang timbul dari kesepakatan akad jual beli adalah kafâlah bi al-mâl bagi kedua belah pihak, baik penjual maupun pembeli. Karena keduanya sama-sama mempunya kewajiban akibat dari sahnya akad jual beli tersebut, yakni kewajiban menyerahkan barang yang dijual bagi penjual, dan kewajiban menyerahkan uang sebagai pengganti barang yang dibeli bagi pembeli.

Apabila dilihat dari ketentuan pasal 37 dimana terjadi musyawarah dan mencapai kesepakatan tentang harga tanah yang akan diberi ganti rugi, maka dari sudut pandang konsep kafâlah, Undang-Undang Nomor 2 Tahun 2012 tersebut sudah sah. Tetapi jika dilihat pasal berikutnya yakni pasal 38 yang menjelaskan bahwa jika tidak terjadi kesepakatan antara pemilik tanah dengan pihak panitian pengadaan tanah, maka keputusan hukum diselesaikan oleh Pengadilan Negeri hingga Mahkamah Agung di tingkat kasasi, ${ }^{14}$ maka hal ini tentunya tidak dapat dilikat dengan perspektif fiqh muamalah - baik dalam sudut pandang teori kafâlah muapun teori jual beli - dan bahkan dapat dikatakan bertentangan dengan asas-asas fiqh muamalah, karena masalah ini dapat dikatakan diluar lingkup kajian fiqh muamalah.

Untuk menjelaskan hal ini ada baiknya jika di sini disinggung mengenai asas-asas dalam fiqh muamalah, yaitu:

\section{(1) Dalam transaksi muamalah harus didasarkan pada persetujuan dan kerelaan kedua}

\section{belah pihak.}

Karena persetujuan dan kerelaan kedua belah pihak yang melakukan transaksi merupakan asas yang sangat penting untuk keabsahan setiap akad. Hal tersebut didasarkan pada firman Allah dalam surat al-Nisa' ayat 19 yang artinya, "Hai orang-orang yang beriman, janganlah

\footnotetext{
${ }^{13}$ Ahmad Wardi Muslih. 2013, Fiqh Muamalat, (Jakarta: Amzah), hal. 443-444.

${ }^{14}$ Lihat Undang-Undang Nomor 2 Tahun 2012 pasal 38 hingga pasal 44.
} 
kamu saling memakan harta sesamamu dengan jalan yang batil, kecuali dengan jalan perniagaan yang berlaku dengan suka sama suka di antara kamu. Dan janganlah kamu membunuh dirimu. Sesungguhnya Allah adalah Maha Penyayang kepadamu."

Dari ayat tersebut kemudian muncul qaidah dalam fiqh muamalah yang berbunyi:

$$
\text { الرضا سيد الاحكام }
$$

"Keridhaan adalah dasar semua hukum (muamalah)."

Untuk menunjukkan adanya kerelaan dalam setiap akad atau transaksi dilakukan ijab dan qabul atau serah terima antara kedua belah pihak yang bertransaksi. Jika kesepakatan tidak tercapai maka masing-masing pihak yang berakad boleh membatalkan transaksinya. Namun demikian hal ini tidak terjadi pada pelaksanaan ganti rugi pengadaan tanah sebagaimana yang diatur dalam Undang-Undang Nomor 2 Tahun 2012. Undang-Undang tersebut mengatur bahwa jika tidak terjadi kesepakatan maka harus diputuskan oleh Pengadilan Negeri atau Mahkamah Agung. Jadi di sini pihak yang menanggung atau pembeli (dalam hal ini pemerintah) seakanakan memaksakan terjadinya akad kafâlah atau dapat juga disamakan dengan akad jual beli. Dalam konsep fiqh muamalah, adanya unsur pemaksaan dalam akad menjadi salah satu penyebab batalnya akan itu sendiri.

\section{(2) Adat kebiasaan dapat menjadi dasar hukum.}

Dalam masalah muamalah, adat kebiasaan yang berlaku dalam masyarakat dapat dijadikan sebagai landasan hukum dengan syarat adat tersebut diakui dan tidak bertentangan dengan ketentuan-ketentuan umum yang ada dalam syara'. Hal ini sebagaimana ditetapkan dalam qaidah:

\section{العادة محكمة}

"Adat kebiasaan digunakan sebagai dasar hukum.",15

Qaidah tersebut didasarkan pada hadis Rasulullah saw "Sesuatu yang oleh orang muslim dipandang baik, maka di sisi Allah juga dianggap baik (pula). "16

Ibnu Nujaim mendefinisikan adat sebagai "Suatu ungkapan dari apa yang terpendam dalam diri, perkara yang dilakukan berulang-ulang yang dapat diterima oleh akal sehat."17

${ }^{15}$ Jalaluddin al-Suyuthi, Al-Asybah wa al-Nadhâ'ir fi Qawâ'id wa Furû' fiqh al-Syafi 'iyah, (Beirut: Dâr al-Kutub al-Ilmiah, 1411 H), hal. 60.

${ }^{16}$ Ibid.

${ }^{17}$ Ibnu Nujaim, Al-Asybah wa al-Nadhâ 'ir 'alâ Mazhabi Abî Hanîfah al-Nu'mân, (Beirut: Dâr alKutub al-Ilmiyah, 1413 H), hal. 100. 
Berkaitan dengan definisi di atas ada dua poin penting yang harus diperhatikan;

Pertama, sesuatu dikatakan sebagai adat apabila terjadi berulang-ulang dan diketahui sesuatu tersebut adalah sesuatu yang mengandung kebaikan. Adat biasanya berhubungan dengan tata nilai yang dipegang oleh suatu masyarakat dimana perbuatan itu dianggap baik. Jadi adat dalam hal ini merupakan perbuatan yang dianggap baik dan benar oleh manusia secara umum yang dilakukan secara berulang-ulang sehingga menjadi kebiasaan.

Kedua, adat tersebut dapat diterima oleh akal sehat, artinya suatu adat yang dapat dijadikan sebagai landasan hukum adalah untuk hukum-hukum yang tidak tegas disebutkan dalam al-Qur'an dan Sunnah dan adat tersebut secara pasti tidak mengandung kemudharatan bagi manusia dan tidak bertentangan dengan syari'at Islam. Selain itu adat tersebut juga tidak menyebabkan kesulitan seperti memboroskan harta, hura-hura, adanya paksaan dan lain sebagainya.

Menurut Imam Izzuddin Ibn Abd al-Salam, kemaslahatan dan kemafsadatan dunia dan akhirat tidak dapat diketahui kecuali dengan syari'ah yang diturunkan Allah melalui Rasul-Nya. Sedangkan kemaslahatan dan kemudharatan dunia dapat diketahui dengan pengalaman, adat kebiasaan, perkiraan yang benar serta indikator. ${ }^{18}$ Di sinilah adat mengambil peran hukum atas parkara-perkara dinamis yang terus terjadi dalam kehidupan manusia hingga saat ini.

Salah satu bentuk dari adat atau kebiasaan masyarakat di Indonesia terutama di Jawa adalah adanya perbuatan yang dilakukan sesuai hasil musyawarah yang dilakukan bersama, misalnya tentang terjadinya kesepakatan pemberian ganti rugi antara yang memberi dan yang menerima ganti rugi dalam masalah besaran dan nilainya. Jika tidak terjadi kesepakatan maka masing-masing pihak tidak boleh memaksakan pihak lain untuk melepaskan haknya. Karena itu musyawarah harus dilakukan berulang-ulang hingga tercapai kesepakatan. Adat tersebut tentunya menjadi bagian dari adat yang dapat dijadikan sebagai landasan hukum dalam transaksi muamalah, selama dalam adat tersebut tidak bertentangan dengan syari'ah secara umum dan terperinci, juga tidak bertentangan dengan akal sehat dalam arti tidak menyebabkan kemudharatan bagi pihak lain.

Namun aturan yang ada dalam Undang-Undang pengadaan tanah tidak menerapkan prinsip musyawarah seperti itu, melainkan musyawarah seakan-akan hanya sebagai bentik hal.10.

${ }^{18}$ Izzuddin Ibn Abd al-Salâm, Qawâ'id al-Ahkâm fî̀Mashâlih al-Anâm, (ttp: Dâr al-Jail, 1980), 
formalitas saja, karena ujung-ujungnya adalah pemaksaan penghilangan hal milik orang melalui jalur Pengadilan. Hal seperti itu tentu saja bertentangan dengan prinsip kedua fiqh muamalah ini.

\section{(3) Tidak boleh merugikan diri sendiri dan orang lain.}

Setiap transaksi dalam hubungan muamalah, termasuk dalam jual beli tidak boleh menimbulkan kerugian kepada diri sendiri dan orang lain. Hal ini didasarkan pada qaidah fiqh yang pokok berikut:

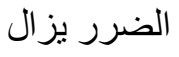

"Kemudharatan harus dihilangkan."19

Qaidah tersebut berasal dari sebuah hadis Nabi saw berikut:

$$
\text { ل الا ضرر و لا ضرار }
$$

“Janganlah merugikan diri sendiri dan janganlah merugikan orang lain. "20

Sebagaimana diketahui bahwa tujuan syari'at Islam adalah untuk mewujudkan kemaslahatan dan menolak kemudharatan. Jika diturunkan kepada tataran yang lebih konkret maka maslahat membawa kemanfaatan sedangkan mudharat membawa kerusakan atau kerugian. Menurut Muhammad Daud Ali, hubungan muamalah apapun bentuk dan teknisnya boleh dilakukan asal hubungan tersebut dapat mendatangkan kebaikan, berguna dan berfaedah bagi kehidupan pribadi dan masyarakat, meskipun tidak ada ketentuannya dalam al-Qura'an dan Sunnah. $^{21}$

Adapun jika qaidah ini dikaitkan dengan masalah ganti rugi pengadaan tanah untuk pembangunan kepentingan umum, maka sebenarnya tidak terlalu berpengaruh dengan aturanaturan dalam Undang-Undang di atas. Hanya saja, yang menjadi kekhawatiran penulis adalah jumlah besara ganti rugi yang ditetapkan oleh Pengadilan Negeri dan atau Mahkamah Agung yang kemudian menjadi dasar pemberian ganti rugi atas tanah. Dalam hal ini apakah putusan yang diberikan benar-benar objektif sehingga tidak ada pihak yang dirugikan, ataukah putusan yang dimaksud ada unsur pemihakan kepada pemerintah atau pihak-pihak yang terlibat dalam proyek pengadaan tanah? Jika yang disebutkan terakhir ini yang terjadi, maka tentu saja aturan pengadaan tanah untuk kepentingan umum yang tertera dalam Undang-Undang tersebut bertentangan dengan asas fiqh muamalah yang ketiga ini.

\footnotetext{
${ }^{19}$ Jalaluddin al-Suyûthî, Al-Asybâh wa al-Nadhâ 'ir, hal. 59.

${ }^{20}$ Hadis riwayat Ibnu Majah.

${ }^{21}$ Muhammad Daud Ali. 2004. Hukum Islam, (Jakarta: Raja Grafindo Persada ), hal. 132-138.
} 
Berdasarkan hasil analisis yang penulis lakukan, setidaknya ada dua poin dalam aturan pemberian ganti rugi atas proyek pengadaan tanah yang diatur oleh Undang-Undang Nomor 2 Tahun 2012 yang tidak sejalan dengan konsep fiqh muamalah, khususnya yang berkaitan dengan konsep kafâlah, yaitu:

Pertama, berkaitan dengan madhmûn/makfûl lahu (pemilik tanah yang ditanggung) dan makfûl bih (objek pertanggungan). Dalam konsep kafâlah, madhmûn/makfûl lahu atau pihak yang tertanggung harus jelas dan diketahui keberadaannya, demikian pula objek kafâlah harus jelas dan tidak majhul atau dalam sengketa, setidaknya menurut pendapat mazhab Hanafiyah dan Syafi'iyah, serta Ibn Hazm. ${ }^{22}$ Bahkan Abu Hanifah dan al-Syafi'i mensyaratkan bahwa untuk terjadinya kafâlah yang sah, untuk menjadi penanggung harus mendapatkan persetujuan terlebih dahulu dari tertanggung. ${ }^{23}$ Adapun dalam Undang-Undang Nomor 2 Tahun 2012 pasal 42 ayat 1 dan 2 dinyatakan bahwa ganti rugi akan dilakukan dengan cara menitipkan uang ganti rugi kepada Pengadilan Negeri setempat dalam kondisi pemilik tanah tidak diketahui keberadaannya, objek tanah yang akan diberikan ganti rugi sedang menjadi objek perkara di pengadilan; masih dipersengketakan kepemilikannya; diletakkan sita oleh pejabat yang berwenang; atau masih menjadi jaminan di bank. Di sinilah nampak perbedaan yang nyata antara konsep kafâlah dalam fiqh muamalah dengan aturan ganti rugi dalam Undang-Undang Nomor 2 Tahun 2012.

Kedua, adanya unsur ikrâh dalam tahapan aturan pemberian ganti kerugian atas pengadaan tanah. Seperti yang telah disepakati oleh jumhur ulama bahwa adanya ikrâh (tekanan atau paksaan) merupakan unsur yang dapat merusak keabsahan suatu akad. Adapun definisi ikrâh adalah tekanan atau paksaan kepada manusia dengan jalan menyakiti atau memberikan ancaman yang mana dengannya seseorang akan mengerjakan atau meninggalkan suatu perbuatan yang diinginkan oleh orang yang melakukan paksaan tersebut. ${ }^{24}$ Ikrâh sendiri terbagi menjadi dua, yakni ikrâh muljî̀' (paksaan yang berat) dan ikrâh ghairu muljî̀' (paksaan yang tidak berat). Bentuk dari ikrâh muljî̀ biasanya seseorang dipaksa dengan ancaman pembunuhan atau yang semisalnya untuk melakukan atau meninggalkan suatu perbuatan. Sedangkan bentuk ikrâh

\footnotetext{
${ }^{22}$ Wahbah Zuhaili. 1986, Fiqh al-Islâm wa Adillatuhu, juz 5, (Damaskus: Dâr al-Fikr), hal. 147.

${ }^{23}$ Lihat Muhammad Ibn Ahmad Ibn Rusyd al-Qurthubi, Bidâyah al-Mujtahid wa Nihâyah alMuqtashid, jus 2, (Kairo: Maktanah al-Taufiqiyah, tth), hal. 371.

24 Mustafa Ahmad Zarka. 1425 H, Al-Madkhal al-Fiqh al-'Amm, juz 1, (Beirut: Dâr alSyamiyah), hal. 452.
} 
ghairu muljî' adalah ancaman baik berupa pemukulan ataupun perkataan yang tidak sampai pada pembunuhan atau yang semisal dengannya. ${ }^{25}$

Seperti yang telah dijelaskan sebelumnya bahwa dalam Undang-Undang Nomor 2 Tahun 2012 pasal 38 dinyatakan bahwa apabila dalam musyawarah tersebut tidak dicapai kesepakatan antara pemilik tanah dengan panitian pengadaan tanah, maka pemilik tanah dihimbau untuk mengajukan keberatan ke Pengadilan Negeri setempat dalam waktu 14 hari kerja. Dalam pasal ini juga dinyatakan bahwa apabila pemiliki tanak masih keberatan dengan hasil putusan Pengadilan negeri, maka dihimbau untuk mengajukan kasasi ke Mahkamah Agung dalam waktu paling lama 14 hari kerja setelah putusan tersebut diterimanya. Pasal berikutnya, yakni pasal 39 ditegaskan bahwa dalam keadaan dimana pemilik tanah menolak besaran ganti rugi yang telah ditetapkan panitia pengadaan tanah, tetapi tidak mengajukan keberatan ke Pengadilan Negeri dalam waktu yang ditetapkan Undang-Undang, maka pemilik tanah dianggap menerima besaran ganti rugi tersebut.

Aturan seperti ini menurut pandangan penulis adalah bentuk dari ikrâh atau paksaan dalam transaksi muamalah, meskipun dilakukan melalui aturan perundang-undangan. Namun demikian penulis merasa kesulitan sehingga tidak dapat memastikan ikrâh semacam ini termasuk ikrâh muljî̀' atau ikrâh ghairu muljî'. Karena paksaan dalam transaksi muamalah dengan bentuk aturan perundang-undangan belum penulis temukan rujukannya dalam beberapa literatur fiqh yang telah penulis kaji.

\section{Perspektif Fiqh Siyasah}

Dalam konsep fiqh siyasah, apabila seorang pemimpin yang telah dipilih telah dibaiat secara sah, maka mereka yang memilih serta seluruh rakyat dengan tidak ada pengecualian diwajibkan mentaatinya, tunduk serta menjalankan segala peraturan yang dibuat dan dijalankan (termasuk undang-undang) selama teraturan-peraturan dan perintahnya tersebut tidak bertentangan dengan hukum Allah dan Rasul-Nya.

Salah satu ayat dalam al-Qur'an yang patut menjadi rujukan tentang hukum wajibnya mentaati pemimpin adalah surat al-Nisa' ayat 59 berikut:

$$
\text { يأيها الذين أمنوا أطيعوا الله وأطيعوا الرسول و أولي الأمر منكم }
$$

"Wahai orang-orang yang beriman, tatatilah Allah dan taatinya Rasul-Nya dan ulil amri di antara kamu."

\footnotetext{
${ }^{25} \mathrm{Ibid}$, hal 453.
} 
Di antara makna "ulil amri" adalah orang-orang yang mewakili urusan rakyat banyak dalam ketaatan kepada Allah dan Rasul-Nya. ${ }^{26}$ Secara umum ayat tersebut menyerukan kepada orang-orang yang beriman untuk mentaati pemimpin-pemimpin mereka selama pemimpin tersebut tidak mengajak kepada kedurhakaan kepada Allah dan Rasul-Nya.

Sebelum ayat 59 ini, yakni surat al-Nisa' ayat 58 telah menjelaskan bahwa seorang pemimpin yang diangkat oleh rakyatnya diwajibkan menunaikan amanat kepada yang berhak menerimanya. Ibnu Taimiyah dalam bukunya yang berjudul al-Siyâsah al-Syar'iyah fí Islâh alRâ'i wa al-Râ'iyah sebagaimana dikutip oleh Munawir Sjadzali menjelaskan bahwa di antara makna “amanah" dalam ayat tersebut adalah dalam pengelolaan kekayaan negara dan pengurusan serta perlindungan atas harta benda dan hak milik rakyat. Mengenai pengelolaan kekayaan negara dan perlindungan harta benda milik warga negara, rakyat tidak dibenarkan menolak peraturan-peraturan yang ditentukan oleh negara. Sebaliknya, negara diwajibkan mengelola harta benda milik negara - yang sebagian sumbernya berasal dari rakyat - sesuai dengan petunjuk al-Qur'an dan Sunnah. ${ }^{27}$

Hal ini apabila dikaitkan dengan peraturan pemberian ganti rugi pengadaan tanah dalam Undang-Undang Nomor 2 Tahun 2012 maka berarti peraturan yang berupa undang-undang yang telah disepakati oleh presiden sebagai eksekutif dan DPR RI sebagai legislatif haruslah ditaati, karena peraturan tersebut dibuat dalam rangka mengelola kekayaan milik negara dan rakyat yang bertujuan untuk kepentingan umum seperti yang tertera pada judul Undang-Undang tersebut. Memang bisa jadi aturan yang dibuat oleh pemerintah bertentangan dengan fiqh secara umum, tetapi tidak berarti bertentangan dengan al-Qur'an dan Sunnah secara tegas. Karena terkadang pemerintah lebih memahami kondisi rakyat yang dipimpinnya serta kemaslahatan daripada konsep-konsep fiqh yang ditulis pada ruang dan waktu atau konteks yang berbeda-beda.

Adapun qaidah fiqh yang sejalan dengan pemikiran ini adalah:

$$
\text { تصرف الإمام على الرعية منوط بالمصلحة }
$$

“Kebijakan seorang pemimpin terhadap rakyatnya bergantung kepada kemaslahatan. ,28

Makna qaidah ini tidak berarti bahwa setiap kebijakan dan aturan yang dibuat oleh pemerintah selalu berorietasi kepada kemaslahatan, tetapi kewajiban kepada pemerintah yang

\footnotetext{
${ }^{26}$ Imam Jalalain, Tafsîr al-Qur'ân al-Karîm, (ttp: Dâr al-Nas al-Misriyah, tth), hal. 79-80.

${ }^{27}$ Munawir Sjadzali, Islam dan Tata Negara, Ajaran, Sejarah, dan Pemikiran, (Jakarta: UI Press, 1993), hal. 83-87.

${ }^{28}$ Ibnu Nujaim, Al-Asybah wa al-Nadhâ'ir, hal. 137.
} 
bertanggung jawab terhadap kepentingan rakyat yang dipimpinnya untuk membuat aturan-aturan yang berorientasi kepada kemaslahatan seluruh rakyatnya. Atas dasar qaidah tersebut sekali lagi penulis katakan bahwa terkadang suatu aturan yang diputuskan oleh pemerintah tampak bertentangan dengan aturan-aturan fiqh secara rigid (terperinci), tetapi aturan tersebut justru sejalan dengan kemaslahatan yang lebih besar.

Contoh yang dapat disebutkan dalam konteks ini adalah perbuatan Umar bin Khathab ketika menjabat sebagai khalifah, ia memutuskan agar Muhamamd bin Maslamah al-Anshari memperbolehkan tetangganya, al-Dhahak bin Qais untuk mengalirkan sungai yang berada di tanah miliknya. Karena sungai yang dialirkan tersebut dapat memberikan manfaat untuk tetangganya dan tidak merugikan Muhammad bin Maslamah. Sebelumnya Muhammad melarang tetangganya melakukan hal itu, dan tetangganya mengatakan kepadanyaa "Mengapa engkau melarangku melakukan sesuatu yang bermanfaat bagimu, padahal kamu dapat mengambil air dari sungai tersebut siang dan malam, dan ini juga tidak merugikan durumu?" Karena Muhammad bin Maslamahh sebagai pemilik tanah tetap melarang, kemudian masalah tersebut diadukan kepada Umar. Maka Umar berkata kepada Muhammad, "Kenapa engkau melarang saudaramu melakukan sesuatu yang bermanfaat baginya dan tidak merugikan kamu?" Tetapi Muhammad tetap bersikeras tidak mengijinkan. Maka Umar berkata, "Demi Allah dia benarbenar akan mengalirkannya, sekalipun di atas perutmu!” Lalu Umar memerintahkan al-Dhahak untuk terus mengalirkan sungai tersebut di atas tanah Muhammad, dan al-Dhahak pun melakukannya. ${ }^{29}$

Apabila dilihat sepintas apa yang dilakukan oleh Umar telah melanggar hak individu orang lain. Tetapi karena kedudukannya sebagai kepala Negara yang mengetahui kemaslahatan rakyatnya, maka semestinya perbuatan Umar tersebut dapat dibenarkan. Karena itu dapat dikatakan bahwa taat kepada Allah dan Rasul diwajibkan, tetapi ketaatan tersebut harus disertai dengan ketaatan kepada pemerintah karena ketaatan kepada Allah dan Rasul tidak akan sempurna tanpa ketaatan kepada pemerintah. Dengan demikian taat kepada pemerintah adalah wajib pula hukumnya. Hal ini sejlaan dengan qaidah fiqh al-'ammah yang berbunyi:

$$
\text { ما لا ينم الو اجب إلا به فهو واجب }
$$

${ }^{29}$ Yusuf al-Qardhawi. 1420 H, Taisîr al-Fiqh al-Muslim al-Mu'âshirah fî Dhau' al-Qur'ân wa al-Sunnah, (Mesir: Maktabah Wahbah ), hal. 90-91. 
"Suatu kewajiban yang tidak sempurna pelaksanaannya kecuali dengan adanya suatu hal, maka suatu hal tersebut wajib pula hukumnya."

Seperti yang diketahui bahwa pembangunan infrastruktur di Indonesia yang pada saat ini sedang digalakkan oleh pemerintah dilakukan untuk memperoleh angka pertumbuhan ekonomi yang maksimal. Apabila ekonomi negara meningkat, secara otomatis akan mempengaruhi tingkat kesejahteraan bagi rakyat. Apabila kesejahteraan rakyat meningkat tentunya akan ada lebih banyak hal yang dapat ditingkatkan dalam rangka taat kepada Allah dan Rasul-Nya. Daji dapat disimpulkan bahwa pengadaan tanah untuk pembangunan kepentingan umum memiliki relevansi dengan kemaslahatan rakyat banyak. Sehingga mentaati aturan pemerintah tentang masalah ini adalah kewajiban rakyat demi terwujudnya kemaslahatan bangsa dan Negara.

\section{KESIMPULAN}

Berdasarkan hasil kajian di atas, setidaknya ada dua poin yang menjadi kesimpulan penulis dalam penelitian ini, yaitu: Pertama, dalam perspektif fiqh muamalah, aturan tentang ganti rugi pengadaan tanah untuk kepentingan umum telah sejalan dengan konsep kafâlah pada tahapan paling awal, yaitu tahapan musyawarah dan pemberian ganti rugi setelah disepakati besaran ganti ruginya. Namun dalam tahap berikutnya dimana pemilik tanah atau tertanggung tidak menyepakati besaran ganti ruginya, aturan pemberian ganti rugi dalam Undang-Undang Nomor 2 Tahun 2012 tidak sejalan dengan konsep kafâlah secara khusus, dan prinsip-prinsip fiqh muamalah secara umum. Selain itu, ketidaksesuaian tersebut juga penulis temukan pada masalah kondisi tertanggung dan objek yang ditanggung atau tanah yang kepada pemiiknya akan diberikan ganti rugi. Kedua, dalam perspektif fiqh siyasah, aturan tentang ganti rugi pengadaan tanah untuk kepentingan umum dapat dikatakan sejalan dengan qaidah dan konsep fiqh siyasah. Karena pembangunan untuk kepentingan umum memiliki relevansi dengan kemaslahatan bangsa dan Negara, maka suatu aturan hukum yang mengaturnya pun harus ditaati oleh seluruh rakyat Indonesia demi terwujudnya kemaslahatan tersebut.

\section{DAFTAR PUSTAKA}

Ali, Muhammad Daud. (2004), Hukum Islam, (Jakarta: Raja Grafindo Persada). Al-Jaziri, Abdurrahman. Fiqh 'alâ Madzâhib al-Arba'ah, juz 3, (Beirut: Dar al-Fikr, tth). 
Al-Qardhawi. (1420 H), Yusuf. Taisîr al-Fiqh al-Muslim al-Mu'âshirah fî Dhau' al-Qur'ân wa al-Sunnah, (Mesir: Maktabah Wahbah).

Al-Qurthubi, Muhammad Ibn Ahmad Ibn Rusyd. Bidâyah al-Mujtahid wa Nihâyah alMuqtashid, jus 2, (Kairo: Maktanah al-Taufiqiyah, tth).

Al-Salâm, Izzuddin Ibn Abd. (1980), Qawâ'id al-Ahkâm fî̀Mashâlih al-Anâm, (ttp: Dâr al-Jail).

Al-Suyuthi. (1411 H) Jalaluddin. Al-Asybah wa al-Nadhâ'ir fi Qawâ'id wa Furû' fiqh alSyafi'iyah, (Beirut: Dâr al-Kutub al-Ilmiah).

Jalalain, Imam. Tafsîr al-Qur'ân al-Karîm, (ttp: Dâr al-Nas al-Misriyah), tth.

Limbong, Bernhard. (2011), Pengadaan Tanah Untuk Pembangunan :Regulasi, Kompensasi Penegakan Hukum, (Jakarta: Pustaka Margaret).

Majallah al-Ahkâm al-Adliyah. (2012), pasal 416, (Istanbul: Marmara Universitesi Yayinlari).

Muslih, Ahmad Wardi.(2013), Fiqh Muamalat, (Jakarta: Amzah).

Nujaim, Ibnu. (1413 H), Al-Asybah wa al-Nadhâ'ir 'alâ Mazhabi Abî Hanîfah al-Nu'mân, (Beirut: Dâr al-Kutub al-Ilmiyah).

Rubaie, Achmad. (2007), Hukum Pengadaan Tanah Untuk Kepentingan Umum, (Malang: Bayumedia Publishing).

Sabiq, Sayid. (1981), Fiqh al-Sunnah, juz 3, (Beirut: Dar al-Fikr).

Sjadzali, Munawir. (1993), Islam dan Tata Negara, Ajaran, Sejarah, dan Pemikiran, (Jakarta: UI Press).

Undang-Undang Nomor 2 Tahun 2012.

Yildiz, Kemal. (2013) Islam Sorumluluk Hukuku, (Istanbul: Marmara Universitesi Ilahiyat Fakultesi Yayinlari).

Zarka, Mustafa Ahmad. (1425 H), Al-Madkhal al-Fiqh al-'Amm, juz 1, (Beirut: Dâr alSyamiyah).

Zuhaili, Wahbah. (1986), Fiqh al-Islâm wa Adillatuhu, juz 5, (Damaskus: Dâr al-Fikr). 